Çukurova Üniversitesi Eğitim Fakültesi Dergisi

Vol: 50 Numb: 2 Page: 663-676

https://dergipark.org.tr/tr/pub/cuefd

\title{
DMC and Individual Differences: A Path Analytical Investigation in Turkish EFL Context \\ Aycan DEMIR AYAZ ${ }^{\mathrm{a}^{*}}$ (ORCID ID - 0000-0001-8105-434X) İsmail Hakkı ERTEN ${ }^{b}$ (ORCID ID - 0000-0002-8527-5681)
}

a Orta Doğu Teknik Üniversitesi, Eğitim Fakültesi, Ankara/Türkiye

${ }^{\mathrm{b}}$ Hacettepe Üniversitesi, Eğitim Fakültesi, Ankara/Türkiye

\section{Article Info}

DOI: 10.14812/cufej.949967

Article history:

Received 09.06.21

Revised 18.09.21

Accepted 22.09.21

Keywords:

$D M C$,

self-regulated strategy use,

language learning effort,

ideal L2 self,

vision.

\section{Abstract}

Directed motivational currents (DMCs) is a novel construct investigated by motivation researchers. Earlier studies on DMCs have focused on explaining its unique nature while the individual difference (ID) factors impacting upon its power and long-term sustainment has been under-researched. The aim of this research study was to reveal the structural interactions among DMC dispositions, self-regulated strategy use, language learning effort, ideal $L 2$ self and imagination capacity/vision of tertiary level EFL learners in Turkish higher education context. The study was conducted with 305 participants and it employed a quantitative research design. Data were collected using a composite survey instrument. Findings showed that imagination capacity, ideal L2 self, language learning effort, and self-regulated strategy use had direct or indirect effect on DMC experience. It is probable, therefore, that these ID factors could help explain long-term existence of DMCs depending on the strength of their predictive power. On the basis of these findings, providing learners with vision-setting and visionsustaining activities, encouraging them to put effort into the learning process and teaching them how to self-regulate via some external interventions were proposed to enhance the strength and sustainment of this unique experience.

\begin{tabular}{ll}
\hline \multicolumn{2}{c}{ Hedefli Motivasyo } \\
\hline Makale Bilgisi \\
\hline DOI: $10.14812 /$ cufej.949967 \\
\hline Makale & Geçmişi: \\
Geliş & 09.06 .21 \\
Düzeltme & 18.09 .21 \\
Kabul & 22.09 .21 \\
\hline
\end{tabular}

Anahtar Kelimeler: hedefli motivasyon akımları, öz-düzenleme stratejileri, dil öğrenme çabası, ideal ikinci dil benliği, vizyon. \section{Öz}

Hedefli motivasyon akımları, motivasyon araştırmacıları tarafından çalışılmakta olan yeni bir kavramdır. Önceki çalışmalar, bu akımların yapısını açıklamaya odaklanırken, gücünü ve uzun vadeli sürdürülebilirliğini etkileyen bireysel farklılık faktörleri henüz yeterince araştırılmamıştır. Bu çalışmanın amacı, Türk yükseköğretim bağlamında İngilizce öğrenenlerin hedefli motivasyon akımı eğilimleri, öz-düzenleme stratejileri kullanımları, dil öğrenme çabaları, ideal ikinci dil benlikleri ve görselleştirme becerileri/vizyonları arasındaki yapısal etkileşimleri ortaya çıkarmaktır. Çalışma 305 katılımcı ile yürütülmüş ve nicel araştırma deseni kullanılmıştır. Veriler, değişkenlere ait ölçüm araçlarının bir araya getirilmesiyle hazırlanan bir nicel ölçüm aracı kullanılarak toplanmıştır. Bulgular, görselleştirme becerisinin, ideal ikinci dil benliğinin, dil öğrenme çabasının ve öz-düzenleme stratejileri kullanımının hedefli motivasyon akımları deneyimi üzerinde doğrudan veya dolaylı etkileri olduğunu göstermiştir. Bu nedenle, bu bireysel farklılık faktörlerinin, yordama güçlerine bağlı olarak, hedefli motivasyon akımlarının sürdürülebilirliğini açıklamaya yardımcı olabilecekleri sonucuna varılmıştır. Bu bulgulara dayanarak, öğrenenlere vizyon belirleme ve vizyon sürdürme etkinlikleri sağlamak, onları öğrenme sürecinde çaba sarf etmeye teşvik etmek ve bazı dış müdahaleler yoluyla öz-düzenlemeyi öğretmek, hedefli motivasyon akımlarının gücünü ve sürdürülebilirliğini artırmak için önerilmektedir.

*Author: egurel@aku.edu.tr 


\section{Introduction}

Directed motivational currents (DMCs) entered the field of language learning psychology quite recently in 2010s. It refers to an intensive and goal-directed process empowering learners to perform at outstandingly immense levels that would not be expected of them under everyday circumstances (Muir \& Dörnyei, 2013). Being a vision-oriented construct, DMCs described language learning motivation as a dynamic construct (Dörnyei, Ibrahim \& Muir, 2015). While the first studies of DMCs focused on explaining its unique nature and validating its structure, individual difference (ID) factors impacting upon its power and long-term sustainment has been under-researched (Safdari \& Maftoon, 2017; Selçuk \& Erten, 2017). The idea behind this study has been motivated by the lack of studies on the ID factors affecting DMC experience. The literature suggests that the concepts of self-regulation, L2 learning effort, imagery capacity, and ideal L2 self are closely related factors to L2 motivation (Chapman \& Tunmer, 1995; Kormos \& Csizer, 2014; Schunk, 1996; Zimmerman, 2000), and they may directly or indirectly influence learners' chance of experiencing DMCs. Thus, the interactions among these ID variables and DMC dispositions need to be uncovered to empower more learners to have that unique experience while learning English as a foreign language.

For a systematic investigation of the relationship network among self-regulation, L2 learning effort, imagery capacity, ideal L2 self, and DMC experience, path analysis was conducted. Based on the studies reported in the literature, a model on the interactions of the variables has been hypothesized (see Figure 1). In the hypothesized model, direct paths from ideal $L 2$ self to $L 2$ learning effort and from $L 2$ learning effort to self-regulated strategy use have been foreseen based on Kormos and Csizer's (2014) findings. Thus, an indirect path from ideal L2 self to self-regulation has been hypothesized via the mediation of learning effort. Vision has been directly linked to learning effort in the hypothesized model (Dörnyei \& Kubanyiova, 2014). A direct path from vision to ought to L2 self and ideal L2 self has also been assumed (Dörnyei \& Chan, 2013; Murray, 2013). An indirect path from vision to self-regulation has been hypothesized via ideal L2 self and effort. Direct paths from vision and self-regulation to DMCs have also been presumed considering the definition provided by Dörnyei, İbrahim, and Muir (2015) stating that DMCs "can be seen as vision-led self-regulation along a fitting, made-to-measure pathway that augments and sustains exerted effort" (p. 103). Finally, a direct path from learning effort to DMCs has been hypothesized based on the same study. The model was tested using path analysis, and the researcher endeavored to indicate the direct and indirect relationships among the variables.

\section{Literature Review}

\section{L2 Motivation and DMC}

The beginning of the millennium was the time when L2 motivation has been described from a dynamic perspective rather than explaining it as a stable construct. Since it has been acknowledged that it is a "dynamic, process oriented manner" (Dörnyei et al., 2016, p. 28), the role of vision in L2 motivation gained more prominence. Vision has been defined as the learners' individual illustrations of their future goal states (Dörnyei \& Chan, 2013, Dörnyei, Ibrahim \& Muir, 2015; Dörnyei, Muir \& Ibrahim, 2014; Henry, Davydenko \& Dörnyei, 2015; Ibrahim, 2016; Muir \& Dörnyei, 2013) and considered as the construct that could energize the long-term effort leading the learners to sustain their motivated behavior (Dörnyei et al., 2016). Being a vision-oriented concept, DMCs entered the field as an explanation of the enduring motivated behavior.

A DMC has been defined as "a prolonged process of engagement in a series of tasks which are rewarding primarily because they transport the individual towards a highly valued end" (Dörnyei et al., 2015 , p. 98). It is such a powerful drive that it is clearly identifiable by the people who witness it (Dörnyei et al., 2014). It has "the capacity to align the diverse factors that are simultaneously at work in a complex system, thereby acting as a regulatory force" (Dörnyei et al., 2016, p. 96). Much of the studies conducted on DMCs thus far endeavored to explain its theoretical constituents (Dörnyei et al., 2014, 2015, 2016; Muir \& Dörnyei, 2013). Since DMCs is a dynamic concept affected by individual, temporal, and circumstantial factors, it shows great variations that make it hard for the researchers to define and 
investigate that construct empirically. Despite its unpredictable nature, three main hallmarks, which are goal/vision-orientedness, well-tailored pathways and positive emotionality, help resolving its complexity to some extent.

\section{The hallmarks of DMC}

Dörnyei et al. (2016) called DMCs "directed" due to its directional feature from the source of motivation to the desired goal. In DMCs, a specific end goal is always available, which distinguishes it from flow experience, and every single action is taken to attain that goal. Vision, proximal sub-goals and self-concordant goals are core features in DMC experiences (Henry et al., 2015). Vision has been defined as "the imitative representation of real or hypothesized events" (Pham \& Taylor, 1999, p. 250). Muir and Dörnyei (2013) state that it causes "emotional reactions" (p. 358) for the learners and as they have already experienced and tasted success in their visions, the urge to make it real does not allow learners to abandon their effort. Besides vision, regular proximal sub-goals are also of great value in DMC experiences to pursue the energy current. According to Bandura and Schunk (1981), while distal goals seem inaccessible to be achieved, proximal ones are shorter term and guide the individual on the way to the expected end. Another way helping learners personalize the goals is warranting that they are selfconcordant. Self-concordant goals are deeply connected with the identity of individuals (Sheldon \& Elliot, 1999). Clearly, they need to be in line with the learners' beliefs, values, interests, wishes, desires and so on.

A well-tailored facilitative structure is the second recognizable feature of DMC experiences. "Functioning as a perceptual route map" from the initiation of the current to the end of it (Henry et al., 2015 , p. 331), the structure contributes to the accomplishment of the final goal in an effective way. As clarified by Dörnyei et al. (2015), the pathway is composed of three main factors that are behavioral routines, affirmative feedback, and sub-goals and progress checks. Behavioral routines suggest following a set of practices that are perceived as the indispensable parts of the current (Dörnyei et al., 2016). Commonly used as an educational instrument, feedback helps foster the explicitness of the criteria for success. Lastly, sub-goals are milestones in directing the current to the end goal. Besides providing directionality, they enable learners to evaluate their development and create the essential energy for sustaining the motivated behavior (Dörnyei et al., 2016).

The third component of DMCs, which has been described as its magical aspect, is positive emotionality. That "mysterious" and "magic" feature (Dörnyei et al., 2016, p. 100) can be described as the satisfaction and enjoyment felt by learners in the current throughout the whole process (Dörnyei et al., 2016). It is associated with the sense that the person is doing something valuable, beneficial, and significant leading to the target goal in the end (Dörnyei et al., 2014).

\section{Previous studies on DMCs}

The initial studies by Dörnyei and his companions (Dörnyei et al., 2015; Muir \& Dörnyei, 2013) analyzed the structure of DMCs theoretically. Then, they have been followed by new lines of research with different foci to comprehend the construct in more detail. A small number of them were dedicated to revealing the validity of its core features with empirical data for distinct cases (Safdari \& Maftoon, 2017; Zarrinabadi \& Tavakoli, 2017) and they affirmed the construct in their cases with all three components validated in that unique experience. Besides, the motivational and affective fluctuations in DMCs were scrutinized looking into cases in Turkish context with different motivational profiles (Sak, 2019; Selçuk \& Erten, 2017). Finally, Zarrinabadi et al. (2019) initiated a new research trend looking into the interactions between DMC experiences and individual difference factors, specifically autonomy, willingness to communicate, self-confidence and self-concept. Sak (2021) followed the agenda investigating DMCs in relation to the five-factor model (FFM) personality traits.

The review presented above suggests that though various lines of research has been initiated in relation to DMC construct, they are still in their infancy and further investigations are fundamental to extend the literature. The current study is distinctive in that it aims to explain variations in DMCs in relation to ID factors that may regulate its power and sustainment. It aims to make a unique 
contribution to the field with different ID factors from the previous studies by Zarrinabadi et al. (2019) and Sak (2021). The study is focused on investigating to what extent the variations in DMCs can be explained by self-regulation, language learning effort, ideal L2 self, and imagination capacity. The following section is devoted to describing the stated ID factors.

\section{Individual Difference Factors}

The ID factors included in the study, namely self-regulation, language learning effort, ideal L2 self, and imagination capacity, were all strongly connected with $L 2$ motivation. Thus, they will be described below referring to their interactions with it. The ties between these ID factors will also be touched upon briefly.

Zimmerman (2000, p.14) described self-regulation as "self-generated thoughts, feelings, and actions that are planned and cyclically adapted to the attainment of personal goals". Pertaining to the interactions between self-regulation and motivation, some researchers define motivation as a precursor for self-regulation (Zimmerman \& Schunk, 2008; Kormos \& Csizer, 2014) while others suggest that selfregulation is, reciprocally, effective in increasing students' motivation (Vidal-Abarca, Mana, \&Gil, 2010; Bembenutty, 2011). Besides these two different views, a mutual interaction between them has also been identified in the literature, and Zimmerman and Schunk (2008) define it as "chicken-and-egg dilemma" (p.4). Zimmerman (2000) presents that when students have high levels of motivation, they put effort and time into self-regulating their behavior and learning processes, and when they are selfregulated and successful in doing that, they get more and more motivated to sustain the learning process.

Effort, which is the equivalence of the term volition in educational psychology, refers to the energy spent on studying to learn a skill or subject area, complete a task, or meet the expectations of significant others related to learning (Carbonaro, 2005). Gardner (2001) states that the motivation to learn a language requires taking action for the goal, and the action stage corresponds to the effort put into the process. Thus, it can be concluded that foreign language learning effort is "composed of motivated acts geared towards learning a non-native language" (Karabiyık \& Mirici, 2018, p. 374). Learning effort is considered as the overlapping point of self-regulatory and motivational constructs (Kormos \& Csizer, 2014). The relationship between them is not much complicated though. Language learning effort as a motivated action activates self-regulated strategy use of the learners (Kormos \& Csizer, 2014) and causes autonomous learning in the end. Reciprocally, self-regulated strategies guide the learners' effort to act successfully in the learning process (Zimmerman, 1989).

At the beginning of the new millennium, changes in the understanding of the motivation concept resulted in the development of a new theory named L2 Motivational Self-System by Dörnyei (2005). It has been rooted from the Possible Selves Theory by Markus and Nurius (1986) and ideal L2 self was one of its main components. Ideal L2 self is "representation of all the attributes that a person would like to possess (e.g., hopes, aspirations, desires)" (Csizer \& Dörnyei, 2005, p. 616). It refers to the promotionfocused self, which includes a clear vision of favorable future goal such as learning English in order to improve professionally and feel success (Csizer \& Dörnyei, 2005).

Imagination capacity, or vision in other words, is grounded on the Possible Selves Theory by Markus and Nurius (1986), and it is in very close interaction with future self-guides. It has been defined in SLA context by Muir and Dörnyei (2013) as "the mental representation of the sensory experience of a future goal state" (p. 357). Vision is presented by some researchers among the strongest determiners of L2 motivation stimulating enduring effort on the part of the learners (Dörnyei \& Kubanyiova, 2014). It is also suggested to increase L2 motivation by helping learners create a clear ideal L2 self (Dörnyei \& Chan, 2013; Murray, 2013).

In this study, investigating the DMCs construct in relation to various individual difference factors (i.e. self-regulated strategy use, L2 learning effort, ideal L2 self, and imagination capacity) was targeted. The research question below was formulated in line with this purpose: 
Demir-Ayaz \& Erten- Çukurova Üniversitesi Eğitim Fakültesi Dergisi, 50(2), 2021, 663-676

- Is the hypothesized model of DMCs appropriate for the Turkish EFL learners in terms of explaining the relationships between their DMC dispositions and the related ID factors (selfregulated strategy use, L2 learning effort, ideal L2 self, and imagination capacity)?

\section{Method}

\section{Research design}

A survey design was adopted by the researchers. In a survey study, a representative sample of participants is included rather than the whole population and the results can be generalized to the whole population. Survey studies are advantageous in that they give researchers the opportunity to contact a large number of participants at a time, thus increasing the reliability and generalizability of the findings. In this study, a cross-sectional survey design was practiced, and a 66-item composite survey instrument was used to collect the data.

\section{Setting and participants}

The study was conducted at the Social Sciences University of Ankara, School of Foreign Languages. The students of that prep-school belong to nine different departments which are Business Administration, Bachelor of Arts in Law, Economy, Political Science and Public Administration, Psychology, International Relations, Sociology, History, and English Language and Literature. Except for the Bachelor of Arts in Law, which has thirty percent English medium instruction for undergraduate students, the other departments teach the undergraduate courses a hundred percent in English. The participants were chosen via convenience sampling. 305 adult learners of English as a foreign language took part in it and their ages ranged between 18 and 28.

\section{Instrumentation}

For the study, quantitative data were collected via a 66 -item composite survey instrument. The variables in it were DMC disposition, self-regulated strategy use, L2 learning effort, ideal L2 self, and imagery capacity. A 5-point Likert scale was preferred. The instrument included 5 control items to ensure that it was not filled in mechanically.

For the quantitative data of the participants' DMC dispositions, DMC Disposition Questionnaire developed and validated by Muir (2016) was conducted. Muir (2016) reported high internal consistency of the scale, $\alpha=.84$. In this study, Turkish version of the scale adapted from Gümüş (2019), who reported high reliability score $(\alpha=.85)$, was utilized.

To collect data on the self-regulated strategy use of the participants, Self-regulated Foreign Language Learning Strategy Questionnaire (Srfllsq) by Habok and Magyar (2018) was preferred. Habok and Magyar (2018) calculated internal consistency scores for each subscale and the results were as follows: $\alpha=.84$ for metacognitive scale, $\alpha=.75$ for cognitive scale, $\alpha=.77$ for meta-affective scale, $\alpha=.88$. The instrument was translated into their L1, Turkish, by the researcher. To ensure that there was no meaning difference or loss between the original and translated versions of the questionnaires, translation and back-translation procedures were performed. During that process professional English majors with Ph.D. degrees and two native speakers of English assisted. Finally, the semantic similarity disclosed 9.5/10 mean score.

L2 learning effort of the participants was measured via the Foreign Language Learning Effort Scale (FLLES) by Karabıyık and Mirici (2018). The scale was specifically designed for tertiary-level EFL learners in Turkey, and therefore perfectly fitted the participants of the current study. Cronbach's alpha score of the scale was presented $\alpha=.85$ by the designers of it.

Ideal L2 self of the learners in this study were estimated via the subscale adapted from Taguchi, Magid, and Papi's (2009) questionnaire. The questionnaire has been adopted by Dörnyei and Chan (2013) as well and they reported quite satisfactory results $(\alpha=.78)$. The Cronbach's alpha value for the Turkish version of it was reported to be $\alpha=.92$ by Demir-Ayaz (2016), which was highly satisfactory. 
To find out the imagination capacity of the respondents, the scale by Kim and Kim (2014) was employed. The Cronbach's alpha coefficient score of the scale was reported to be $\alpha=.72$ by Kim and Kim (2011), reflecting acceptable internal consistency of the scale. A translated version of the scale by the researcher was employed for ease of understanding on the part of the respondents and highly satisfactory synonymy values were revealed between the original and its translated versions (9.6/10).

\section{Data collection and analysis}

Subsequent to the approval of the Hacettepe University Ethics Commission in April 2019, the study was conducted through the end of the 2019-20 spring term. Data were collected at the beginning of their class time and it took around 15 minutes. The data for this study were retrieved from the first researcher's Ph.D. dissertation.

The purpose of the research question was testing the hypothesized model of DMCs in Turkish EFL context, and showing the relationships between the participants' DMC dispositions, self-regulated strategy use, L2 learning effort, imagination capacity, and ideal L2 self. Therefore, path analysis technique which is a subcategory of structural equation modelling (SEM) and enabling the researchers to examine the relationships among the observed variables (Kline, 2005) was applied. IBM SPSS AMOS statistical software was used to analyze that research question.

\section{Validity and Reliability Measures}

To ensure validity and reliability of the scales, the path analysis was preceded by confirmatory factor analysis (CFA). Prior to these analyses, data were cautiously screened and preliminary analyses were conducted. Then, indices of goodness-of-fit such as degrees of freedom ratio (X2/df), the Goodness-ofFit Index (GFI), Adjusted Goodness-of-Fit Index (AGFI), the Comparative Fit Index (CFI), and the Root Mean Square Error of Approximation (RMSEA) were administered for each scale. As a result of the CFA, all of the scales used in the current study were confirmed to have construct validity based on their factor loading coefficients, the fit indices and t-values.

In addition, the reliability coefficients of the modified scales were presented to ensure their internal consistency. To indicate the reliability of the model, composite reliability scores were also calculated. In table 1 below, the results for each scale were summarized.

Table 1.

A summary of the psychometric properties of the scales

\begin{tabular}{cccccccc}
\hline Scale & $\mathbf{X}^{\mathbf{2} / \mathbf{d f}}$ & GFI & AGFI & CFI & RMSEA & $\boldsymbol{\alpha}$ & $\boldsymbol{C R}$ \\
\hline DMC disposition & 3.28 & .94 & .90 & .91 & .08 & .82 & .80 \\
Self-regulated strategy use & 1.83 & .92 & .90 & .92 & .05 & .83 & .88 \\
Language learning effort & 2.41 & .92 & .89 & .91 & .06 & .70 & .89 \\
Ideal L2 self & 3.91 & .94 & .89 & .96 & .08 & .89 & .90 \\
Imagination capacity & .40 & .99 & .99 & 1.00 & .00 & .75 & .73 \\
\hline
\end{tabular}

The fit indices showed that $\mathrm{X}^{2} / \mathrm{df}$ ratio scores of the scales ranged from .40 to 3.91 . All of them were below the cut-off value of 5 and represented perfect fit. The GFI scores were between .92 and .99, the CFI scores were between .91 and 1.00. They were all above the minimum value of .90. Additionally, the AGFIs were calculated to range from .89 to .99 which were acceptable since they were around the cutoff score of .90. The RMSEA values appeared to be between .00 and .08 . They were equal to or less than the maximum cut-off point of .08, thus indicating good fit. Finally, the Cronbach's alpha and composite reliability scores of the scales were computed and the results were acceptable for each one since they were equal to or above the threshold value of .70 .

\section{Results}

Following the statistical analysis of construct validity and internal consistency, further inferential statistics, namely path analysis, was appropriate to be performed. The hypothesized model to be tested 
was created by the researchers based on the literature. Both direct and indirect effects with multiple mediators were estimated among the variables. Multiple mediator models were suggested to be more advantageous than separate single mediation models by Preacher and Hayes (2008). They stated that testing multiple mediators in one model gives the opportunity to see the mediation effect of each variable in the presence of the others. To do so, a complex model was suggested to be tested by the researchers (see Figure 1).

To test the model, fit indices were administered, path coefficients were examined, and the significance levels of both direct and indirect paths were checked via two-tailed tests. T-values $(\geq \pm 1.96$, Jöreskog \& Sörbom, 1993) and p-values ( $\leq .05)$ were the criteria for the significance of direct paths. Bootstrapping, which is a process of creating replications from the data to compute the significance of the indirect effects, was used (set at 2000) (Tabachnick \& Fidell, 2012).

Table 2.

Goodness of fit statistics of the hypothesized model

\begin{tabular}{cccccccc}
\hline & $\mathbf{X}^{2}$ & $\mathbf{d f}$ & $\mathbf{X}^{2} / \mathbf{d f}$ & GFI & AGFI & CFI & RMSEA \\
\hline $\begin{array}{c}\text { Hypothesized } \\
\text { model }\end{array}$ & .481 & 1 & .48 & .99 & .98 & 1.00 & .00 \\
\hline
\end{tabular}

Note. $X^{2}=$ chi-quare; $d f=$ degrees of freedom; GFI = goodness-of-fit index; $A G F I=$ adjusted goodness-offit index; $C F I=$ comparative fit index; RMSEA = root mean square error of approximation

A close inquiry of the suggested model provided perfect goodness-of-fit values. The $\mathrm{X}^{2} /$ ratio was .48 , which was below the cut-off point of 5. GFI was .99, AGFI was found to be .98, CFI was 1.00 and finally RMSEA appeared to be .00, all suggesting an overall fit to the data (see Table 2 above). However, the path coefficients, t-values and significance scores revealed that the hypothesized model needed to be trimmed since one path coefficient was not statistically significant.

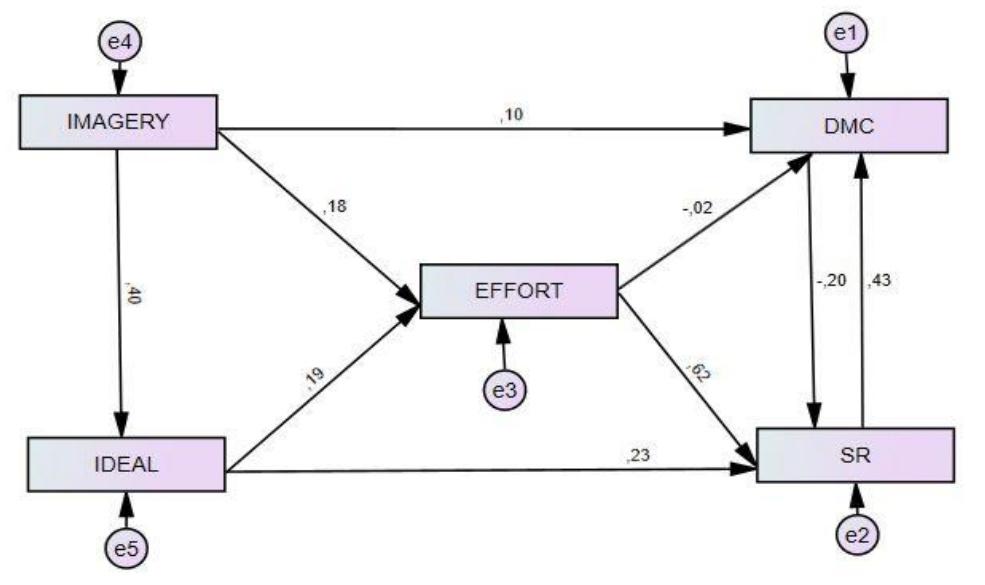

Figure 1. The path coefficients of the hypothesized model

Note. IMAGERY = Imagination Capacity; IDEAL = Ideal L2 Self; EFFORT = Language Learning Effort; DMC = Directed Motivational Currents Dispositions; SR = Self-regulated Strategy Use. Standardized coefficients are displayed in the figures.

The path leading from DMC disposition to self-regulated strategy use appeared to be non-significant. The t-value for it was -1.05 , below the cut-off score of \pm 1.96 (Jöreskog \& Sörbom, 1993). Thus, it was omitted from the model and the model was tested again. After the modification, the goodness of fit statistics provided perfect results again and the path coefficients were all at statistically significant levels. The results for the trimmed model can be seen in Table 3 below. 
Table 3.

Goodness of fit statistics of the modified model

\begin{tabular}{cccccccc}
\hline & $\mathbf{X}^{2}$ & $\mathbf{d f}$ & $\mathbf{X}^{2} / \mathbf{d f}$ & GFI & AGFI & CFI & RMSEA \\
\hline $\begin{array}{c}\text { Modified } \\
\text { model }\end{array}$ & 1.580 & 2 & .79 & .99 & .98 & 1.00 & .00 \\
\hline
\end{tabular}

Note. $X^{2}=$ chi-quare; $d f=$ degrees of freedom; GFI = goodness-of-fit index; $A G F I=$ adjusted goodness-offit index; $C F I=$ comparative fit index; RMSEA = root mean square error of approximation

As shown in the table above, the $\mathrm{X}^{2} /$ ratio was .79 and GFI was computed to be .99 which showed a perfect fit to the data. AGFI was .98 suggesting a perfect fit as well. CFI was 1.00 and RMSEA was found to be .00 , both indicating that the model and the data were in perfect fit. The t-statistics for the new paths provided scores ranging from 1.97 to 12.95 suggesting that they were all significant. The trimmed model can be observed in Figure 2 below.

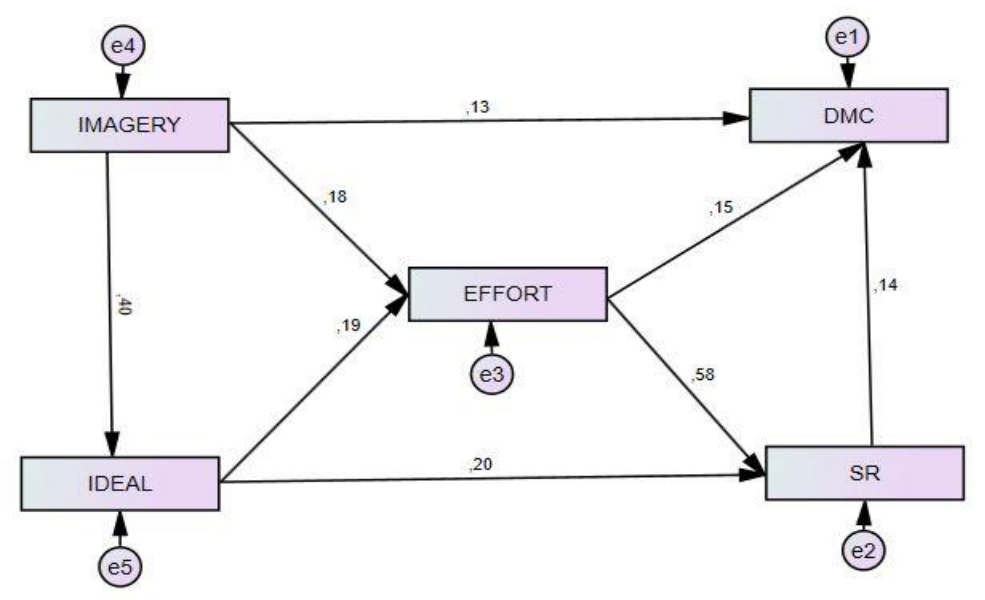

Figure 2. The structural model of DMCs (final model)

Note. IMAGERY = Imagination Capacity; IDEAL = Ideal L2 Self; EFFORT = Language Learning Effort; DMC = Directed Motivational Currents Dispositions; SR = Self-regulated Strategy Use. Standardized coefficients are displayed in the figures.

To investigate the interactions among the variables further, standardized direct and indirect effects were calculated. While a direct effect refers to direct paths between the variables, for the indirect effects between two variables, mediation of another variable is needed (Kline, 2005). Total effect is calculated summing up the direct and indirect effects. To illustrate, the direct effect of ideal L2 self on self-regulated strategy use was .20. Ideal L2 self had an indirect effect as well on self-regulated strategy use via its effect on language learning effort $(.19 \times .58=.11)$. Thus the total effect of ideal $L 2$ self on selfregulated strategy use was $.31(.20+.11=.31)$. Table 4 below summarizes the findings for the final model.

Table 4.

Standardized direct, indirect, and total effects in the final model

\begin{tabular}{cccc}
\hline Path & Direct effect & Indirect effect & Total effect \\
\hline Language learning effort $\rightarrow$ DMCs & .15 & .08 & .23 \\
Imagery $\rightarrow$ DMCs & .13 & .06 & .19 \\
Self-regulated strategy use $\rightarrow$ DMCs & .14 & & .14 \\
Ideal L2 self $\rightarrow$ DMCs & & .07 & .07 \\
Language learning effort $\rightarrow$ Self-regulated & .58 & & .58 \\
strategy use & & & .31 \\
Ideal L2 self $\rightarrow$ Self-regulated strategy use & .20 & .11 & \\
\hline
\end{tabular}


Demir-Ayaz \& Erten- Çukurova Üniversitesi Eğitim Fakültesi Dergisi, 50(2), 2021, 663-676

\begin{tabular}{|c|c|c|c|}
\hline Imagery $\rightarrow$ Self-regulated strategy use & & .22 & .22 \\
\hline Imagery $\rightarrow$ Language learning effort & .18 & .07 & .25 \\
\hline Ideal L2 self $\rightarrow$ Language learning effort & .19 & & .19 \\
\hline Imagery $\rightarrow$ Ideal L2 self & .40 & & .40 \\
\hline
\end{tabular}

According to the table, language learning effort exerted the largest direct (.15) and indirect effects (.08) on DMC disposition. The indirect effect between them was through the mediating role of selfregulated strategy use. Imagery was the second strongest predictor of DMCs with a total effect of .19. While the direct influence of imagery on DMCs was .13, the indirect effect between them via the mediation of effort, ideal L2 self, and self-regulated strategy use was .06. It can be stated according to the model that language learning effort, ideal L2 self, and self-regulated strategy use play a significant role between the learners' imagination capacity and DMC dispositions. Self-regulated strategy use predicted DMCs significantly and directly (.14) suggesting that the learners with high strategy use preferences were more prone to DMC experience. Finally, ideal L2 self influenced DMC experience indirectly (.07), and the relationship between them was mediated via language learning effort and selfregulated strategy use.

Investigating the variables impacting upon self-regulated strategy use, language learning effort appeared to be the strongest one (.58) with a direct path. Thus, it can be stated that increased language learning effort leads to increased strategy preference by the learners. Ideal L2 self had both direct (.20) and indirect (.11) effect on self-regulated strategy use preference of the learners. The indirect relationship between them was through the mediating role of language learning effort. Imagery was the final predictor of self-regulated strategy use. It exerted an indirect influence (.22) on self-regulation through the mediation of ideal $\mathrm{L} 2$ self and language learning effort.

Language learning effort was strongly predicted by imagination capacity of the learners both directly (.18) and indirectly (.07). The direct interaction between them implies that the learners who can create a strong image of their goals put more effort into language learning process. The indirect path between them was through ideal $L 2$ self, so it can be inferred that improved imagination capacity leads to better ideal L2 self, finally increasing the effort to learn the language. The direct path between ideal L2 self and language learning effort was also strong and positive (.19). Finally, imagery exerted its largest direct influence on ideal L2 self (.40). As the learners' imagination capacity increased, they could create a stronger ideal L2 self.

\section{Discussion \& Conclusion}

The aim of the research study was to determine the structural interactions among DMC dispositions and ID characteristics of tertiary level EFL learners in Turkish higher education context. First it should be clarified that since the aforementioned ID factors were not investigated in relation to DMC experience thus far, the discussion will have to be grounded on the studies about L2 motivation and speculate relying on their findings in a broad sense. Considering the strong connection between DMCs and L2 motivation, it is expected not to cause deficiency in the study.

The most evident finding to emerge from the analysis is the predictive relationship between language learning effort and DMCs. Gardner (2001) stated that the motivation to learn a language requires taking action for successful realization of that goal, and the action stage corresponds to the effort put into the process. Thus, it can be asserted that foreign language learning effort is "composed of motivated acts geared towards learning a non-native language" (Karabıyık \& Mirici, 2018, p. 374). Dörnyei and Otto (1998) also provide support for that interaction defining L2 motivation through the amount of intended effort to reach a desired goal, thus emphasizing the role of effort in goalattainment. In addition, language learning effort exerted indirect effect on DMCs via the mediation of self-regulated strategy use. Learning effort is considered as the overlapping point of self-regulatory and motivational constructs since it is included as a significant term in both of them (Kormos \& Csizer, 2014). Effort as a motivated action activates self-regulated strategy use of the learners (Kormos \& Csizer, 2014) 
and causes autonomous learning in the end. Reciprocally, self-regulated strategies guide the learners' effort to act successfully in the learning process (Zimmerman, 1989). Exerting effort into the learning process and sustaining it even in the cases of challenges are presented by many researchers among the characteristics of good self-regulators (Boekaerts, Pintrich, \& Zeidner, 2000; Zimmerman, 1998; Zimmerman \& Schunk, 2001).

The direct relationship between imagination capacity/vision and DMCs is indisputably apparent in the literature. DMCs is a construct significantly based on goal/vision-orientedness (Muir \& Dörnyei, 2013). Muir and Dörnyei (2013) highlight the role of vision in DMC experience as one of its basic components creating the current and causing the long-term sustainment of it until reaching the desired goal. Having a highly valued end goal and creating a strong vision of it in mind are among the basic characteristics of DMC experiences. In addition, Dörnyei, Ibrahim, and Muir (2015) define DMC experience stating that DMCs "can be seen as vision-led self-regulation along a fitting, made-to-measure pathway that augments and sustains exerted effort" (p. 103).

Another important finding was that ideal L2 self had a direct influence on self-regulated strategy use of the learners. In addition to a mediated interaction between ideal L2 self and self-regulated strategy use via learning effort, the direct interaction between them seem to be consistent with earlier research (Csizer \& Kormos, 2009; Dörnyei \& Ushioda, 2009; Iwaniec, 2014). To clarify, Csizer and Dörnyei (2009) stated that since ideal L2 self has intrinsic values on the part of the learners, it prompts the learners to put effort into self-regulation processes. Similarly, Iwaniec (2014) looked into the predictive power of three self-constructs, which were self-efficacy, ideal L2 self and self-concept, on self-regulated strategy use and findings revealed that ideal L2 self had strongest effect on self-regulation while the others would impact upon the strength of ideal $L 2$ self.

The results showing interactions among imagination capacity, ideal L2 self, L2 learning effort, and finally DMCs corroborate the findings of a great deal of the previous work (Dörnyei \& Chan, 2013; Dörnyei \& Kubanyiova, 2014; Kormos \& Csizer, 2014; Murray, 2013). It is suggested in the literature that the capacity for mental imagery was a precursor for creating a vivid vision of ideal L2 self (Al-Shehri, 2009; Dörnyei \& Chan, 2013; Kim, 2009; Kim \& Kim, 2011, 2014; Yang \& Kim, 2011). The learners with strong imagination capacity would be able to create clearer visions of their desired future selves. The significant role of vision in stimulating learning effort has also been supported by various researchers (Dörnyei \& Kubanyiova, 2014; Muir \& Dörnyei, 2013). Muir and Dörnyei (2013) displayed that with the positive emotions resulting from strong images of desired selves, the learners would tend to put greater effort to verify them in their real lives. Thus, in accordance with the previous studies as well, leaners with strong ideal L2 self would put greater amount of effort into the learning process since it would not be sensible to wish for reaching it without any intended learning effort (Kormos \& Csizer, 2014), finally leading to stronger motivation. Impacting upon ideal L2 self and language learning effort, vision could be speculated to be influential in self-regulation via their mediating roles.

Findings revealed a direct relationship between self-regulated strategy use and DMCs showing that self-regulation would predict DMC experience. In line with this finding, Vidal-Abarca, Mana and Gil (2010) suggest a direct interaction between self-regulated strategy use and L2 motivation emphasizing that self-regulation is effective in increasing students' motivation. Bembenutty (2011) also agrees with their findings stating that self-regulation enhances learners' motivation. On the other side, no evidence was detected presenting a predictive power of DMCs on self-regulated strategy use. To clarify, it can be stated that although self-regulated learners have tendency to have DMC experience, being in that current does not entail using self-regulation strategies, which has great support in the literature as well. Literature suggests that DMCs does not require conscious control of the behavior through selfregulation and strategy use because the individual caught up in that current does not see any obstacles to overcome during the process (Dörnyei et al., 2014; Muir \& Dörnyei, 2013). DMCs is defined as an unforced automatic process that both produces and uses the energy needed to function (Dörnyei et al., 2014; Muir \& Dörnyei, 2013), and Dörnyei et al. (2016) stated that it is not possible for the selfregulation to explain for the goal striving in DMC-like constructs. 


\section{Conclusion, Pedagogical Implications, and Limitations}

This study has been the first attempt to thoroughly examine the structural relations among DMC dispositions, self-regulated strategy use, language learning effort, ideal L2 self, and imagination capacity of tertiary level EFL learners. The results of this investigation showed that imagination capacity, ideal L2 self, language learning effort, and self-regulated strategy use had direct or indirect effect on DMC experience. It is probable, therefore, that these ID factors could help explain the long-term existence of the current depending on the strength of their predictive power.

The study offered two pedagogical implications. First of all, the significance of vision-setting activities in language classes to support the learners construct clearer vision of their ideal L2 self has been revealed. In addition, via implementing vision-maintenance activities to help the learners keep their vision alive until reaching their end goal, it would be possible to support the learners for longer terms of this current. With regard to the fact that vision is one of three hallmarks of DMCs, interventions designed to strengthen it would pave the way for more powerful and durable DMC experience. To do so, educators can devise their own activities or refer to the ones designed by Hadfield and Dörnyei (2013) with these purposes. $L 2$ curriculum can also be revised to promote vision setting and vision maintenance skills of EFL learners. Secondly, encouraging the learners to put effort into the learning process and teaching them how to self-regulate via some external interventions, the strength and longer-term sustainment of it could be enhanced. Although DMCs is an intensive drive to act without any conscious control (Dörnyei et al., 2014; Muir \& Dörnyei, 2013), it is a demanding experience leading to great amounts of investment in terms of time and energy throughout the process. Thus, guiding learners in that process may support the sustainment of the current for longer periods. Some adaptations in L2 curriculum to include specific interventions for that skill could help stimulate self-regulated learning behavior of EFL learners.

Being limited to EFL learners in Turkish education context, the findings may not be applicable to other groups of learners out of Turkish education system, which makes them less generalizable. Therefore, this study would be a leading one on that specific topic and provide valuable implications for the learners in that context. In addition, the findings of this study were based on quantitative data retrieved via scales, and supporting them with qualitative research data could provide more insight into the interactions between these ID factors and DMC experiences.

All rules included in the "Directive for Scientific Research and Publication Ethics in Higher Education Institutions" have been adhered to, and none of the "Actions Contrary to Scientific Research and Publication Ethics" included in the second section of the Directive have been implemented.

\section{References}

Bandura, A., \& Schunk, D. H. (1981). Cultivating competence, self-efficacy, and intrinsic interest through proximal self-motivation. Journal of Personality and Social Psychology, 41(3), 586.

Bembenutty, H. (2011). Meaningful and maladaptive homework practices: The role of self-efficacy and self-regulation. Journal of Advanced Academics, 22(3), 448-473.

Boekaerts, M., \& Corno, L. (2005). Self-regulation in the classroom: A perspective on assessment and intervention. Applied Psychology, 54(2), 199-231.

Boekaerts, M., Pintrich, P. R., \& Zeidner, M. (2000). Self-regulation: An introductory overview. In M. Boekaerts, P. R. Pintrich, \& M. Zeidner (Eds.). Handbook of self-regulation (pp. 1-9). Academic Press.

Carbonaro, W. (2005). Tracking, students' effort, and academic achievement. Sociology of Education, 78(1), 27-49.

Chapman, J. W., \& Tunmer, W. E. (1995). Development of young children's reading self-concepts: An examination of emerging subcomponents and their relationship with reading achievement. Journal of Educational Psychology, 87, 154-167. 
Demir-Ayaz \& Erten - Çukurova Üniversitesi Eğitim Fakültesi Dergisi, 50(2), 2021, 663-676

Cohen, J. (1988). Statistical power analysis for the behavioural sciences. Hillsdale, NJ: Laurence Erlbaum Associates.

Csizér, K., \& Dörnyei, Z. (2005). Language learners' motivational profiles and their motivated learning behaviour. Language Learning, 55(4), 613-659.

Demir-Ayaz, A. (2016). The relationship between foreign language learners' future second language (L2) self-guides, language learning motivation and achievement. Unpublished master's thesis. Hacettepe University, Turkey.

Dörnyei, Z. (2005). The psychology of the language learner: Individual differences in second language acquisition. Mahwah, NJ: Lawrence Erlbaum Associates.

Dörnyei, Z., \& Otto, I. (1998). Motivation in action: A process model of L2 motivation. Working Papers in Applied Linguistics (Thames Valley University, London), 4, 43-69.

Dörnyei, Z., \& Chan, L. (2013). Motivation and vision: An analysis of future L2 self images, sensory styles, and imagery capacity across two target languages. Language Learning, 63(3), 437-462.

Dörnyei, Z., \& Kubanyiova, M. (2014). Motivating learners, motivating teachers: Building vision in the language classroom. Cambridge: Cambridge University Press.

Dörnyei, Z., Henry, A., \& Muir, C. (2016). Motivational currents in language learning: Frameworks for focused interventions. New York, NY: Routledge.

Dörnyei, Z., Ibrahim, Z., \& Muir, C. (2015). Directed motivational currents: Regulating complex dynamic systems through motivational surges. In Z. Dörnyei, P. D. Maclntyre, \& A. Henry (Eds.), Motivational dynamics in language learning (pp. 95-105). Bristol: Multilingual Matters.

Dörnyei, Z., Muir, C., \& Ibrahim, Z. (2014). Directed motivational currents: Energising language learning through creating intense motivational pathways. In D. Lasagabaster, A. Doiz, \& J. M. Sierra (Eds.), Motivation and foreign language learning: From theory to practice (pp. 9-29). Amsterdam: John Benjamins Publishing Company.

Gardner, R. C. (2001). Integrative motivation and second language acquisition. In Z. Dörnyei \& R. Schmidt (Eds.), Motivation and second language acquisition (pp. 1-19). Hawaii: University of Hawaii Press.

Ghanizadeh, A., \& Jahedizadeh, S. (2017). Directed Motivational Currents: The implementation of the dynamic web-based Persian scale among Iranian EFL learners. Journal of Teaching Language Skills, 36(1), 27-56.

Gümüş, Ö. (2019). Exploring directed motivational currents of English as a foreign language learners at the tertiary level through the dynamic systems perspective. Unpublished doctoral dissertation. University of Hacettepe, Turkey.

Habók, A., \& Magyar, A. (2018). Validation of a self-regulated foreign language learning strategy questionnaire through multidimensional modelling. Frontiers in Psychology, 9.

Hadfield, J., \& Dörnyei, Z. (2013). Motivating learning. Harlow, England: Pearson.

Hattie, J., \& Timperley, H. (2007). The power of feedback. Review of Educational Research, 77(1), 81-112.

Henry, A., Davydenko, S., \& Dörnyei, Z. (2015). The anatomy of directed motivational currents: Exploring intense and enduring periods of L2 motivation. The Modern Language Journal, 99(2), 329-345.

Iwaniec, J. (2014). 11 Self-constructs in language learning: What is their role in self-regulation?. The impact of self-concept on language learning, 79, 189.

Jöreskog, K. G., \& Sörbom, D. (1993). LISREL 8: Structural equation modeling with the SIMPLIS command language. Scientific Software International.

Karabıyık, C., \& Mirici, i. H. (2018). Development and validation of the foreign language learning effort scale for Turkish tertiary-level students. Educational Sciences: Theory \& Practice, 18(2). 
Demir-Ayaz \& Erten- Çukurova Üniversitesi Eğitim Fakültesi Dergisi, 50(2), 2021, 663-676

Kim, T. Y. (2009). 14. The sociocultural interface between ideal self and ought-to self: A case study of two korean students' ESL motivation. In Z. Dörnyei \& E. Ushioda (Eds.), Motivation, language identity and the L2 self (pp. 274-294). Multilingual Matters.

Kim, T.-Y., \& Kim, Y.-K. (2014). A structural model for perceptual learning styles, the ideal L2 self, motivated behavior, and English proficiency. System, 46, 14-27.

Kim, Y. K., \& Kim, T. Y. (2011). The effect of Korean secondary school students' perceptual learning styles and ideal L2 self on motivated L2 behavior and English proficiency. Korean Journal of English Language and Linguistics, 11(1), 21-42.

Kormos, J., \& Csizér, K. (2008). Age-related differences in the motivation of learning English as a foreign language: Attitudes, selves, and motivated learning behavior. Language Learning, 58(2), 327-355.

Kormos, J., \& Csizer, K. (2014). The interaction of motivation, self-regulatory strategies, and autonomous learning behavior in different learner groups. Tesol Quarterly, 48(2), 275-299.

Markus, H., \& Nurius, P. (1986). Possible selves. American Psychologist, 41, 954-969.

Muir, C. (2016). The dynamics of intense long-term motivation in language learning: Directed Motivational Currents in theory and practice. Unpublished doctoral dissertation. Nottingham: University of Nottingham.

Muir, C., \& Dörnyei, Z. (2013). Directed motivational currents: Using vision to create effective motivational pathways. Studies in Second Language Learning and Teaching, 3, 357-375.

Murray, G. (2013). Pedagogy of the possible: Imagination, autonomy, and space. Studies in Second Language Learning and Teaching, (III-3), 377-396.

Perry, N. E., Phillips, L., \& Hutchinson, L. (2006). Mentoring student teachers to support self-regulated learning. The Elementary School Journal, 106(3), 237-254.

Pham, L. B., \& Taylor, S. E. (1999). From thought to action: Effects of process-versus outcome-based mental simulations on performance. Personality and Social Psychology Bulletin, 25(2), 250-260.

Pietluch, A. (2018). Extraordinary motivation or a high sense of personal agency: The role of self-efficacy in the Directed Motivational Currents theory. New Horizons in English Studies, (3).

Preacher, K. J., \& Hayes, A. F. (2008). Asymptotic and resampling strategies for assessing and comparing indirect effects in multiple mediator models. Behavior research methods, 40(3), 879-891.

Safdari, S., \& Maftoon, P. (2017). The rise and fall of directed motivational currents: A case study. The Journal of Language Teaching and Learning, 7(1), 43-54.

Sak, M. (2019). Contextual factors that enhance and impair directed motivational currents in instructed L2 classroom settings. Novitas-ROYAL (Research on Youth and Language), 13(2), 155-174.

Sak, M. (2021). Understanding the role of personality in explaining L2 learners' DMC disposition. Foreign Language Annals, 1-23.

Schunk, D. H. (1996). Goal and self-evaluative influences during children's cognitive skil learning. American Educational Research Journal, 33, 359-382.

Selçuk, Ö., \& Erten, i. H. (2017). A display of patterns of change in learners' motivation: Dynamics perspective. Novitas-Royal, 11(2).

Sheldon, K. M., \& Elliot, A. J. (1999). Goal striving, need satisfaction, and longitudinal well being: the selfconcordance model. Journal of Personality and Social Psychology, 76(3), 482.

T., Magid, M., \& Papi, M. (2009). The L2 motivational self system among Japanese, Chinese and Iranian learners of English: A comparative study. In Dörnyei, Z., \& Ushioda, E. (Eds.), Motivation, Language Identity and the L2 Self (pp. 66-97). Bristol: Multilingual Matters.

Tabachnick, B. G., Fidell, I. S.(2012) Using multivariate statistics. Boston, MA: Allyn \& Bacon. 
Demir-Ayaz \& Erten - Çukurova Üniversitesi Eğitim Fakültesi Dergisi, 50(2), 2021, 663-676

Ushioda, E. (2003). Motivation as a socially mediated process. In D. Little, J. Ridley, \& E. Ushioda (Eds.), Learner autonomy in the foreign language classroom: Teacher, learner, curriculum and assessment (pp.90-102). Dublin, Ireland: Authentik.

Ushioda, E. (2006). Motivation, autonomy and sociocultural theory. In P. Benson (Ed.), Learner autonomy 8: Insider perspectives on autonomy in language learning and teaching (pp. 5-24). Dublin, Ireland: Authentik.

Vidal-Abarca, E., Mañá, A., \& Gil, L. (2010). Individual differences for self-regulating task-oriented reading activities. Journal of Educational Psychology, 102(4), 817.

Yang, J. S., \& Kim, T. Y. (2011). The L2 motivational self system and perceptual learning styles of Chinese, Japanese, Korean, and Swedish students. English Teaching, 66(1), 141-162.

Zarrinabadi, N., \& Tavakoli, M. (2016). Exploring motivational surges among Iranian EFL teacher trainees: Directed motivational currents in focus. TESOL Quarterly, 51(1), 155- 166.

Zimmerman BJ. (2000). Attainment of self-regulation: A social cognitive perspective. In: Boekaerts $M$, Pintrich PR, \& Zeidner M. (Eds), Handbook of self-regulation (pp. 13-39). San Diego: Academic Press.

Zimmerman, B . J. (1986). Development of self-regulated learning: Which are the key sub processes? Contemporary Educational Psychology, 16,301-313.

Zimmerman, B. J. (1989). A social cognitive view of self-regulated academic learning. Journal of Educational Psychology, 81(3), 329.

Zimmerman, B. J. (1998). Developing self-fulfilling cycles of academic regulation: An analysis of exemplary instructional models. In D. H. Schunk \& B. J. Zimmerman (Eds.), Self-regulated learning: From teaching to self-reflective practice (pp. 1-19). New York, NY: Lawrence Erlbaum.

Zimmerman, B. J., \& Schunk, D. H. (2001). Self-regulated learning and academic achievement: Theoretical perspective. Lawrence Erlbaum ASSOciates, New JerSey.

Zimmerman, B. J., \& Schunk, D. H. (2008). Motivation: An essential dimension of self-regulated learning. In D. H. Schunk \& B. J. Zimmerman (Eds.), Motivation and self-regulated learning: Theory, research and applications (pp. 1-30). New York, NY: Lawrence Erlbaum. 